\title{
The Natural Rehabilitation of Tailing Ponds from Căpuș, Cluj
}

\author{
Aurel MAXIM ${ }^{1}$, Andrei STOIE ${ }^{1}$, Mignon ȘANDOR ${ }^{1}$, Antonia ODAGIU ${ }^{1}$, \\ Viorela PERT,EA ${ }^{1}$, Lucia MIHALESCU ${ }^{2}$ \\ ${ }^{1}$ Department of Environmental and Plant Protection, University of Agricultural Sciences and Veterinary \\ Medicine Cluj-Napoca \\ ${ }^{2}$ Department of Chemistry-Biology, The North University Baia-Mare \\ * corresponding author: maxim0067@yahoo.com
}

Bulletin USAMV series Agriculture 72(1)/2015

Print ISSN 1843-5246; Electronic ISSN 1843-5386

DOI 10.15835/buasvmcn-agr: 11188

\begin{abstract}
Mining industry is one of the most polluting, in particular through the mine tailings and tailing ponds. In Romania, most of these were rehabilitated natural, as is the case at Căpuș.Our studies and research were conducted in 2013 and had two main objectives: to establish natural recovery capacity of the four tailings ponds from the exploitation and processing of iron from from Căpușu Mare (1962-1985), after 28 years from closure, achieving phytocenologic investigations to study the evolution of ecological succession on a lifeless biotope. Genuine identification species installed on the tailings ponds was made by using the dichotomy keys. Quantitative study of characteristics was made by the following indices: coverage using abundance-dominance scale (BraunBlanquet), calculating the frequency and classification in class presence. For this ecological study of vegetation we used stationary research, with the planimetric method using metric frame 1 square $(1 \times 1 \mathrm{~m})$. The coverage of vegetation varies from $87 \%$ (tailing pond I) to $69 \%$ (tailing pond IV). The wood species occupying from $56 \%$ (tailing pond I) of the surface of the tailing pond, to 14\% (tailing pond IV).Floristic inventory conducted shows that the floristic diversity is at the tailing pond III where were identified, 8 species of trees, 3 species of shrubs and 30 herbaceous species. The lower diversity at the tailings pond I can be explained by the high percentage of land cover by wooden species at the expense of herbaceous.

Phytocenologic results of our investigations show that the tailings ponds from Căpuşu Mare are naturally rehabilitated after 28 years, which is the age of the latest pond. Unfortunately there is no description of the dynamics of these phytocenosis. Although species don't have a great economic value, spontaneous vegetation installed here has the advantage of a positive visual impact, setting ponds, preventing air pollution by drifting the tailings by wind and its transport by rain.
\end{abstract}

Keywords: natural rehabilitation, planimetric method, phytocenosis, tailing ponds

\section{INTRODUCTION}

Mining have many negative effects on the environment and human health. First, leading to massive deforestation and releases toxic minerals and heavy metals in soil and water, and even more, mining leads to the release of methane, a greenhouse gas with 20 times effect greater than carbon dioxide. Secondly, mining effects persist for years after the ore is mined, by blocking large areas of land, surfaces that are used to store the sterile (Panizza, and Piacente, 2008, Maxim, 2008).

The mine exploitation is situated in the village Căpușu Mare, Cluj county, village located 30 km west of Cluj-Napoca, left the European road (E 60) Cluj - Oradea (Fig. 1).

Exploitation activities held on the territories of Căpușu Mic, Căpușu Mare and Agârbiciu villages. Capus mining operations took place in an area of 


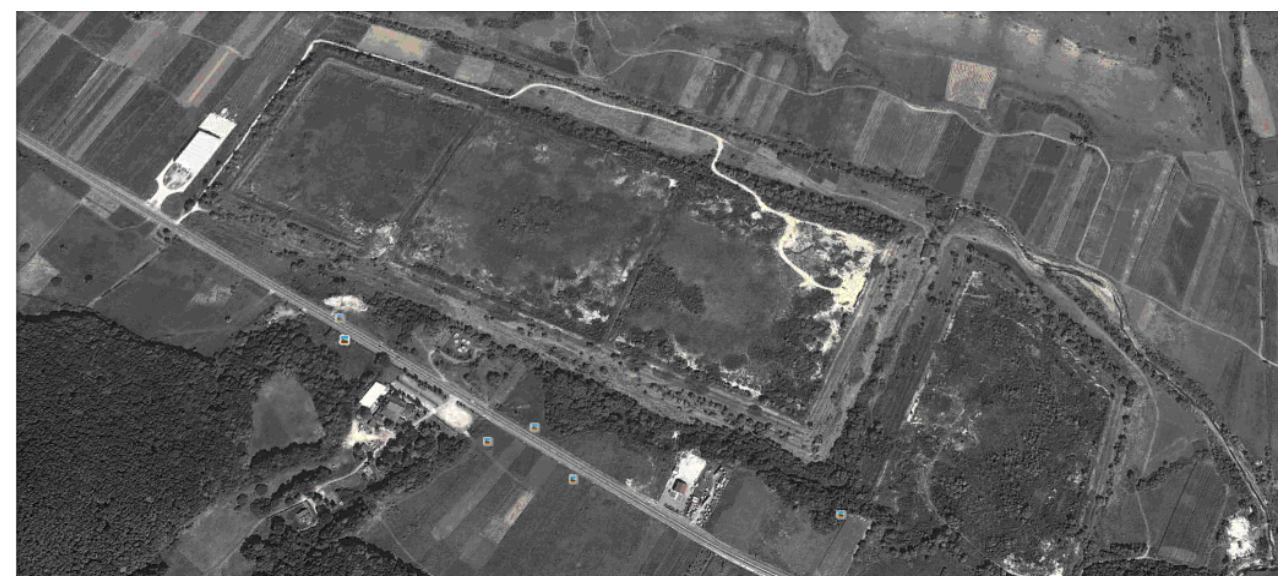

Fig.1. The decantation ponds from Căpuşu Mare, Cluj. Satellite image

over 280 hectares, and the extent of exhaustion the reserves of iron ore exploited, part of the affected area must be restored to agricultural circuit (Blaga, 1981; Blaga and all., 2001; Clapa, 2003).

The subject of activity mattered in operating and preparing iron ores deposit from Căpuș Şatra, Băișoara-Iara and also the dissolution of concentrates obtained by preparing them (Mât, 2012).

Our studies and research have been conducted in 2014 and had two main objectives: to establish natural recovery capacity of the four ponds resulting from the exploitation and processing iron ore from Căpuşu Mare (1962-1985), after 29 years since the cessation; carrying out phytocenologic investigations to study the evolution of ecological succession on a lifeless biotope. Our attention is not focused on very thorough phytosociological studies.

\section{MATERIALS AND METHODS}

Genuine identification species installed on the tailings ponds was made by using the dichotomy keys. Quantitative study of characteristics was made by the following indices: coverage using abundance-dominance scale (Braun-Blanquet), calculating the frequency and classification in class presence. For this ecological study of vegetation we used stationary research, with the planimetric method using metric frame 1 square $(1 \times 1 \mathrm{~m})$.

The abundance-dominance scale used takes into account the abundance:

$r=1-5$ specimens, very low coverage;

$+=$ few specimens, low coverage;
1 = many specimens with low coverage or few specimens with higher coverage;

$2=$ many specimens or coverage up to $1 / 4$ of the area;

$3=$ coverage up to $1 / 4-1 / 2$ of the area, regardless of the number of specimens;

$4=$ coverage up to $1 / 2-3 / 4$ of the area, regardless of the number of specimens;

$5=$ coverage up to $3 / 4$ of the area, regardless of the number of specimens.

Gross table was the first table that has been drawn up and has two entries: species occur in rows and in the columns are the quantitative values that characterize their populations in each surveying. The table of presence was obtained by transcription species from the gross table in decreasing order of their presence. The presence was calculated in percentage using the formula

$\mathrm{P} \times 100 / \mathrm{N}$, were $\mathrm{P}$ is the presence, and $\mathrm{N}$ is the total number of surveys. The values obtained were grouped into 5 classes of presence $(1-20,20-40$, 40-60, 61-80, 81-100\%).

\section{RESULTS AND DISCUTIONS}

The decantation ponds from the mine exploitation from Căpușu Mare, Cluj were built between 1962-1985.

The first decantation pond functioned for about 8 years, since the opening of the exploitation (1962), until 1969.

After 45 years since the pond closed, the degree of coverage of the pond is $87 \%$, and the woodes species occupy about $56 \%$ of the area (fig. 2). 
Floristic inventory conducted reveals the presence of 33 species of vascular plants, as follows: 8 species of trees, 3 species of shrubs and 22 herbaceous species.

Among the species of vascular plants in studied ponds, were installed only species of angiosperms, and among this monocots, there are only exclusive representatives of the Poaceae family.

The tree species are: Betula pendula, Salix alba, Populus tremula, Populus alba, Pyrus pyraster, Salix fragilis, Robinia pseudoacacia and Acer negundo. It was found the presence of three species of shrubs: Hippophae rhamnoides, Rubus fructicosus and Rosa canina.

The herbaceous vegetation on the pond is represented by 22 species:: Phragmites communis, Calamagrostis arundinacea subsp. Brachytricha (Steud.), Festuca sp., Galium mollugo, Vicia sativa, Tussilago farfara, Hypericum perforatum, Achillea milefolium, Poa nemoralis, Sonchus arvensis, Trifolium pratense, Trifolium montanum, Leuchantemum vulgare, Lotus corniculatus, Plantago lanceolata, Onobrychis viciifolia, Medicago sativa, Dactylis glomerata, Daucus carota, Cirsium arvense, Knautia arvensis, Cichorium intybus.
The presence of trees varies form 5 to 14 surveys, out of 20. In shrubs, the presence is 12 on Hippophae rhamnoides, and 6 on Rubus fructicocus și Rosa canina. On herbaceous plants, the values of this indicator is between much larger values, from 9 on Phragmites communis and 2 on Knautia arvensis and Cichorium intybus.

In Table 1 were transcribed species of gross table in order of decreasing their presence. In trees, Salix alba (P = 14), Betula pendula (11) Robinia pseudoacacia (10), Populus tremula (8), Salix fragilis (7), Acer negundo (6), Pyrus pyraster (5), Populus alba (5) and at shrubs, Hippophae rhamnoides (12), Rubus fructicosus (6), Rosa canina (6). Regarding the presence of herbaceous species in descending order was as follows: Phragmites communis (9), Calamagrostis arundinacea subsp. Brachytricha (Steud.) (8), Festuca sp. (8), Galium mollugo (8), Vicia sativa (7), Tussilago farfara (7), Hypericum perforatum (7), Achillea milefolium (7), Poa nemoralis (6), Sonchus arvensis (6), Trifolium pratense (6), Trifolium montanum (6), Leuchantemum vulgare (6), Lotus corniculatus (6), Plantago lanceolata (6), Onobrychis viciifolia (6), Medicago sativa (6), Dactylis glomerata (6),

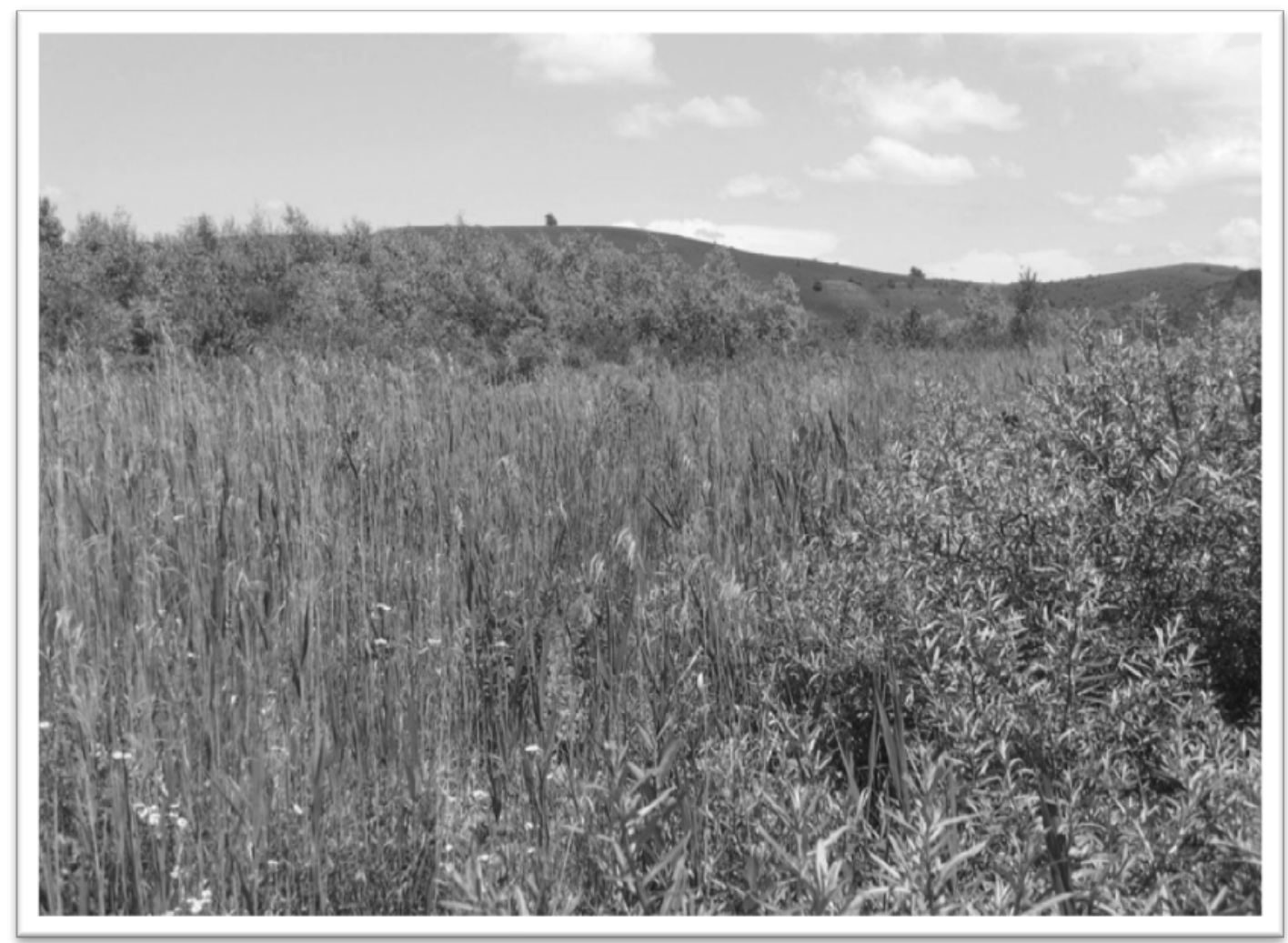

Fig. 2. Decantation pond I from Căpuşul Mare, Cluj, after 45 years since the pond closed 
Daucus carota (5), Cirsium arvense (3), Knautia arvensis (2), Cichorium intybus (2).

The frequency of species was calculated using the formula $\mathrm{P} \times 100$ / N, where $\mathrm{P}$ is the presence and $\mathrm{N}$ is the total number of surveys.. The values obtained were grouped into 5 classes of presence: 1-20, 20-40, 40-60, 61-80, 81-100\% (Table 2).

In trees, the most common species was Salix $a l b a$, with a frequency of $70 \%$, followed by Betula pendula with 55\%, Robinia pseudoacacia 50\%,

Table 1 Table of reports with values of abundance-dominance for the decanting pond I (1962-1969) from Căpuşu Mare, Cluj county, made in 2014

\begin{tabular}{|c|c|c|c|c|c|c|c|c|c|c|c|c|c|c|c|c|c|c|c|c|c|}
\hline \multirow{2}{*}{ Species } & \multicolumn{20}{|c|}{ Survey no. } & \multirow[t]{2}{*}{ Presence } \\
\hline & 1 & 2 & 3 & 4 & 5 & 6 & 7 & 8 & 9 & 10 & 11 & 12 & 13 & 14 & 15 & 16 & 17 & 718 & $8 \quad 19$ & 920 & \\
\hline \multicolumn{22}{|c|}{ Trees } \\
\hline Salix alba & 1 & 2 & - & - & 3 & 4 & 1 & - & - & 4 & 2 & - & 3 & - & 3 & 3 & 2 & 2 & 1 & 4 & 14 \\
\hline Betula pendula & - & 4 & 4 & - & 2 & - & - & 2 & - & 1 & 2 & 4 & - & - & 2 & 2 & - & - & 2 & 3 & 11 \\
\hline Robinia pseudoacacia & 4 & - & 2 & - & - & - & 2 & 2 & - & 3 & - & - & 3 & 2 & 2 & - & 2 & - & 4 & - & 10 \\
\hline Populus tremula & 2 & - & - & 3 & 3 & - & - & 1 & - & - & 2 & - & 3 & 2 & - & 2 & - & - & - & - & 8 \\
\hline Salix fragilis & - & 2 & 1 & - & - & - & - & 2 & 1 & - & - & 2 & - & - & - & - & 2 & 2 & - & - & 7 \\
\hline Acer negundo & - & - & 1 & - & - & 1 & - & - & - & 1 & - & - & - & - & - & - & 2 & 2 & 2 & - & 6 \\
\hline Pyrus pyraster & - & 1 & - & - & - & - & 2 & - & 2 & - & - & - & - & - & 3 & - & - & - & - & 2 & 5 \\
\hline Populus alba & - & - & - & 1 & 2 & - & - & - & 3 & - & - & - & - & 3 & - & - & - & - & 1 & - & 5 \\
\hline \multicolumn{22}{|c|}{ Shrubs } \\
\hline Hippophaë rhamnoides & 3 & - & - & 2 & - & 3 & - & - & - & 3 & 4 & 2 & 3 & 2 & - & 4 & 1 & 3 & - & 1 & 12 \\
\hline Rubus fructicosus & - & - & - & 1 & - & - & 2 & 1 & 2 & - & + & - & - & - & 1 & - & - & - & - & - & 6 \\
\hline Rosa canina & - & - & 2 & - & - & 2 & - & - & - & 1 & - & - & - & + & - & - & - & 2 & - & 3 & 6 \\
\hline \multicolumn{22}{|c|}{ Herbaceous plants } \\
\hline Phragmites communis & - & - & - & 1 & + & - & 3 & 3 & + & + & - & 1 & - & + & - & - & - & - & 1 & - & 9 \\
\hline $\begin{array}{l}\text { Calamagrostis arundinacea } \\
\text { subsp. Brachytricha (Steud.) }\end{array}$ & 1 & - & $\mathrm{r}$ & $\mathrm{r}$ & - & - & 1 & - & - & - & 1 & - & - & + & - & + & - & + & - & - & 8 \\
\hline Festuca sp. & - & - & $\mathrm{r}$ & $\mathrm{r}$ & - & - & - & - & - & $\mathrm{r}$ & + & + & - & - & + & $\mathrm{r}$ & - & + & - & - & 8 \\
\hline Galium mollugo & - & - & 1 & $\mathrm{r}$ & - & - & - & 2 & + & - & - & 1 & - & - & - & - & + & + & $r$ & - & 8 \\
\hline Vicia sativa & - & - & - & - & - & $\mathrm{r}$ & - & + & \pm & - & $\mathrm{r}$ & 1 & 1 & - & - & - & - & $\mathrm{r}$ & - & - & 7 \\
\hline Tussilago farfara & - & - & $\mathrm{r}$ & - & - & - & + & - & r & - & - & 1 & - & - & - & - & - & 1 & $\mathrm{r}$ & + & 7 \\
\hline Hypericum perforatum & - & - & - & + & + & + & - & - & - & - & 1 & + & - & + & + & - & - & - & - & - & 7 \\
\hline Achillea milefolium & - & r & + & - & - & + & - & r & + & - & r & - & + & - & - & - & - & - & - & - & 7 \\
\hline Poa nemoralis & - & + & - & - & + & - & $\mathrm{r}$ & $\mathrm{r}$ & 1 & r & - & - & - & - & - & - & - & - & - & - & 6 \\
\hline Sonchus arvensis & $\mathrm{r}$ & + & + & - & - & - & 1 & - & - & - & $\mathrm{r}$ & - & - & - & $\mathrm{r}$ & - & - & - & - & - & 6 \\
\hline Trifolium pratense & - & - & - & - & + & + & - & 1 & - & $\mathrm{r}$ & $\mathrm{r}$ & + & - & - & - & - & - & - & - & - & 6 \\
\hline Trifolium montanum & - & + & - & - & - & - & $\mathrm{r}$ & - & - & - & - & $\mathrm{r}$ & - & + & - & $\mathrm{r}$ & $\mathrm{r}$ & - & - & - & 6 \\
\hline Leuchantemum vulgare & - & + & - & $\mathrm{r}$ & - & - & + & - & - & - & r & - & - & + & - & - & + & - & - & - & 6 \\
\hline Lotus corniculatus & - & - & - & - & $\mathrm{r}$ & $\mathrm{r}$ & + & - & - & $\mathrm{r}$ & + & $\mathrm{r}$ & - & - & - & - & - & - & - & - & 6 \\
\hline Plantago lanceolata & - & - & - & $\mathrm{r}$ & - & + & - & - & r & $\mathrm{r}$ & + & - & - & - & - & - & + & + & - & - & 6 \\
\hline Onobrychis viciifolia & $\mathrm{r}$ & - & - & - & - & $\mathrm{r}$ & r & - & - & - & - & - & + & - & $\mathrm{r}$ & - & + & - & - & - & 6 \\
\hline Medicago sativa & - & - & - & - & 1 & - & - & 1 & - & + & - & + & - & + & - & - & - & - & + & - & 6 \\
\hline Dactylis glomerata & - & - & 1 & + & - & - & - & $\mathrm{r}$ & - & r & - & - & r & - & + & - & - & - & - & - & 6 \\
\hline Daucus carota & - & - & + & - & $\mathrm{r}$ & - & - & - & $\mathrm{r}$ & - & + & - & - & - & - & - & $\mathrm{r}$ & - & - & - & 5 \\
\hline Cirsium arvense & - & - & - & - & - & - & - & - & - & - & + & - & - & - & r & - & + & - & - & - & 3 \\
\hline Knautia arvensis & - & - & - & - & - & - & - & - & + & - & - & - & 1 & - & - & - & - & - & - & - & 2 \\
\hline Cichorium intybus & - & + & - & - & - & - & - & - & $\mathrm{r}$ & - & - & - & - & - & - & - & - & - & - & - & 2 \\
\hline
\end{tabular}


Populus tremula 40\%, Salix fragilis with 35\%, Acer negundo 30\%, Pyrus pyraster and Populus alba with $25 \%$. A species will fall into the $V$ Class of presence (Salix alba), two species (Robinia pseudoacacia and Betula pendula) falls in the IV Class of presence, and the other five (Populus tremula, Salix fragilis, Pyrus pyraster and Acer negundo, Populus alba) are in the III Class of presence.

It can be seen pioneering installation species of trees, including a high frequency of locust tree (Robinia pseudoacacia) and quite frequently Acer negundo, both species are of North American origin and therefore adventive for the flora of Romania. However that may their installation can be considered with a positive effect because they did not invaded the natural vegetation types; the pond was initially completely devoided of vegetation cover.

The willow and poplar species indicates an excess of moisture in the soil, at least in certain parts of the studied area.

Shrubs are found with Hippophae rhamnoides in $60 \%$ of surveys, Rubus fructicocus and Rosa canina at respectively $30 \%$, and in terms of class presence, Hippophae rhamnoides fall in fourth class of presence, while Rubus fructicocus and Rosa canina fall into class III of presence.

Shrubs are also represented by pioneer species, including especially sea buckthorn (Hippophae rhamnoides) and is characterized by vast capacity for vegetative spreading.

The most common herbaceous species on the decantation pond from Căpușu Mare is Phragmites communis with a presence of $45 \%$ of the surveys, followed by Calamagostris arundinacea subsp Brachytricha (Steud.) with 40\%, Festuca sp. with $40 \%$, Galium mollugo with $40 \%$, Vicia sativa with $35 \%$, Tussilago farfara with 35\%, Hypericum perforatum with $35 \%$, Achillea milefolium with $35 \%$, Poa nemoralis with 30\%, Sonchus arvensis with $30 \%$, Trifolium pratense with $30 \%$, Trifolium montanum with 30\%, Leuchantemum vulgare with $30 \%$, Lotus corniculatus with $30 \%$, Cirsium arvense with $30 \%$, Plantago lanceolata with $30 \%$, Onobrychis viciifolia with $30 \%$, Medicago sativa with 30\%, Knautia arvensis with 30\%, Dactylis glomerata with $30 \%$, Daucus carota with $25 \%$, Cichorium intybus with 25\%, Medicago lupulina with $25 \%$, Vicia tetrasperma with $20 \%$, Carex sp. with 20\%, Erigeron acris with 20\%, Medicago falcata with $20 \%$, Dianthus with $20 \%$, Equisetum arvense with 20\%, Taraxacum officinale with $20 \%$, Silene vulgaris with 20\%, Senecio vulgaris with 20\%, Vicia craca with 15\%, Brachypodium pinnatum with 15\%, Stipa pennata with 15\%, Rhianthus angustifolius with 15\%, Erigeron annuus with 15\%, Papaver rhoeas with 10\%, Lytrum salicarum with 10\%, Erigeron strigosus with 10\% and Lotus corniculatus with $10 \%$.

Regarding the classes of presence, from the amount of 22 herbaceous species, one falls in class IV of presence (Phragmites communis), 18 in class III (Calamagrostis arundinacea subsp. Brachytricha (Steud.), Festuca sp., Galium mollugo, Vicia sativa, Tussilago farfara, Hypericum perforatum, Achillea milefolium, Poa nemoralis, Sonchus arvensis, Trifolium pratense, Trifolium montanum, Leuchantemum vulgare, Lotus corniculatus, Plantago lanceolata, Onobrychis viciifolia, Medicago sativa, Dactylis glomerata, Daucus carota), and 3 in class II (Cirsium arvense, Knautia arvensis, Cichorium intybus).

The most common herbaceous species are graminaceae places with excessive humidity, being like willow and poplar species, well adapted for colonization of land affected by excess moisture.

The tailings pond II functioned during 1969-1975, for 6 years.

Vegetation coverage after 39 years since the pond was closed is $81 \%$, the wooden species occupies about $37 \%$ of the area.

Floristic investigations revealed the presence of 41 species, as follows: 8 species of trees, 3 species of shrubs and 30 herbaceous species.

The tailings pond III worked for about six years, from 1975 to 1981.

After 33 years since the pond was closed, wooden species occupies about $31 \%$ of the surface, and vegetation coverage was $74 \%$.

Floristic studies showed the presence of 40 species, of which 8 species of trees, two species of shrubs and herbaceous species 30 .

The construction of the fourth pond began in 1981 and ended in 1985 with the cessation of operation.

In 2014, after 29 years since the pond was closed, the vegetation coverage is $69 \%$ and the wooden species occupies about $14 \%$ of the area.

Floristic inventory conducted reveals the presence of 40 species, as follows: six species of trees, three species of shrubs and 32 herbaceous species. 
The species identified on pond II, III and IV are approximately the same as in the pond I. Most of the species present on the first pond have been identified as well on pond II, III and IV.

The results of our phytocenologic investigations show that the decantation ponds from Căpuşu Mare are naturally rehabilitated after 28 years, which is also the age of the most recent pond.

Although the species do not have great economic value, spontaneous vegetation installed here has the advantage of a positive visual impact,

Tab. 2. The Frequency and the Classes of Presence of vascular plant species on The Decantation Pond I (1962-1969) from Căpuşu Mare, Cluj County, 2014

\begin{tabular}{|c|c|c|}
\hline Species & Frequency (\%) & Class of Presence (c.) \\
\hline \multicolumn{3}{|l|}{ Trees } \\
\hline Salix alba & 70 & $\mathrm{~V}$ \\
\hline Betula pendula & 55 & IV \\
\hline Robinia pseudoacacia & 50 & IV \\
\hline Populus tremula & 40 & III \\
\hline Salix fragilis & 35 & III \\
\hline Acer negundo & 30 & III \\
\hline Pyrus pyraster & 25 & III \\
\hline Populus alba & 25 & III \\
\hline \multicolumn{3}{|l|}{ Shrubs } \\
\hline Hippophaë rhamnoides & 60 & IV \\
\hline Rubus fructicosus & 30 & III \\
\hline Rosa canina & 30 & III \\
\hline \multicolumn{3}{|l|}{ Herbaceous species } \\
\hline Phragmites communis & 45 & IV \\
\hline $\begin{array}{l}\text { Calamagrostis arundinacea subsp. } \\
\text { Brachytricha (Steud.) }\end{array}$ & 40 & III \\
\hline Festuca sp. & 40 & III \\
\hline Galium mollugo & 40 & III \\
\hline Vicia sativa & 35 & III \\
\hline Tussilago farfara & 35 & III \\
\hline Hypericum perforatum & 35 & III \\
\hline Achillea milefolium & 35 & III \\
\hline Poa nemoralis & 30 & III \\
\hline Sonchus arvensis & 30 & III \\
\hline Trifolium pratense & 30 & III \\
\hline Trifolium montanum & 30 & III \\
\hline Leuchantemum vulgare & 30 & III \\
\hline Lotus corniculatus & 30 & III \\
\hline Plantago lanceolata & 30 & III \\
\hline Onobrychis viciifolia & 30 & III \\
\hline Medicago sativa & 30 & III \\
\hline Dactylis glomerata & 30 & III \\
\hline Daucus carota & 25 & III \\
\hline Cirsium arvense & 15 & II \\
\hline Knautia arvensis & 10 & II \\
\hline Cichorium intybus & 10 & II \\
\hline
\end{tabular}


setting the ponds, preventing air pollution by drifting the tailings by wind and its transport by rainwater.

\section{CONCLUSIONS}

On Tailing Ponds from Căpus, the coverage of vegetation varies from $87 \%$ (tailing pond I) to $69 \%$ (tailing pond IV). The wood species occupying from $56 \%$ (tailing pond I) of the surface of the tailing pond, to $14 \%$ (tailing pond IV).

Floristic inventory conducted shows that the floristic diversity is at the tailing pond III where were identified, 8 species of trees, 3 species of shrubs and 30 herbaceous species. The lower diversity at the tailings pond I can be explained by the high percentage of land cover by wooden species at the expense of herbaceous.

Phytocenologic results of our investigations show that the tailings ponds from Căpuşu Mare are naturally rehabilitated after 28 years, which is the age of the latest pond. Unfortunately there is no description of the dynamics of these phytocenosis. Although species don't have a great economic value, spontaneous vegetation installed here has the advantage of a positive visual impact, setting ponds, preventing air pollution by drifting the tailings by wind and its transport by rain.

\section{REFERENCES}

1. Blaga Gh (1981). Cercetări pentru redarea în folosință agricolă a terenurilor degradate de exploatări miniere în zona Căpuş - Aghireș. Teză de doctorat, Institutul Agronomic, Timişoara

2. Blaga Gh, Bunescu V, Răuță C, Lechințan T, Paulette L, Clapa D (2001). Unele aspecte privind refacerea terenurilor degradate de exploatarea minieră la zi de la Căpuş, jud. Cluj. Lucrările Simpozionului SNRSS Filiala Oltenia Craiova, 310-315

3. Clapa D (2003). Cercetări privind protosolurile antropice din Transilvania, Cluj-Napoca.

4. Teză de doctorat,Cluj- Napoca

5. Maxim A (2008). Ecologie generală și aplicată. Ed. Risoprint, Cluj-Napoca.

6. Mâț S (2012). Structura și dinamica vegetației pe haldele de steril de la Căpuș, Cionca și Aghireș (jud. Cluj). Teză de doctorat,Cluj- Napoca.

7. Panizza M, Piacente S (2008). Geomorphites and geotourism. Geogr. Acadêmica 2(1):5-9 